\title{
FOREST STRUCTURE AND REGENERATION PATTERN OF BETULA UTILIS D. DON IN MANASLU CONSERVATION AREA, NEPAL
}

\author{
Hishila Sujakhu, Kamal Raj Gosai and Siddhi Bir Karmacharya \\ Khwopa College, Tribhuvan University, Dekocha, Bhaktapur \\ Email: hishila21@gmail.com
}

\begin{abstract}
Forest structure and regeneration of Betula utilis (D. Don) was studied in birch forest located in Samagaun valley $(3500-4000$ m) of Manaslu Conservation Area. Vegetation sampling was done by quadrat method. Altogether 40 quadrats were sampled to determine the Importance Value Index (IVI) of tree species, and distribution pattern of seedlings and saplings. Regeneration was assessed by density - diameter curve. Four tree species were recorded from the forest. Betula utilis was the dominant tree species with the highest Importance Value Index (173.22) in mixed Betula forest and 262.96 in pure Betula forest and Abies spectabilis was the co - dominant species (65.95) in mixed Betula forest while Rhododendron campanulatum was the co-dominant species (37.03) in pure Betula forest. Density of Betula utilis increased with increase in elevation where as density of other tree species decreased with increase in elevation. Mixed Betula forest at lower elevation was young. The density diameter curve of the tree population of Betula utilis, both on mixed and pure forests, deviated slightly from the typical reverse $\mathbf{J}$ shaped structure and hence did not show the sustainable regeneration. The sapling density was higher than seedling density. The distribution of seedlings and saplings were not uniform among the sampling plots.
\end{abstract}

Key words: Abies spectabilis, density-diameter curve, Samagaun, saplings and seedlings.

\section{INTRODUCTION}

Betula utilis D. Don (Bhojpatra) forms tree line vegetation all along the Nepal Himalayas and extensive stands of this species can be found on northern shady slopes and ravine areas (TISC 2002). It is the only broadleaved angiosperm tree species in the Himalayas which dominates an extensive area at subalpine altitudes (Zobel and Singh 1997). Betula spp. show a high freezing tolerance (Sakai and Larcher 1987) which enables them to form a tree line in the Himalayas as well as in the Scandinavian region (Cairns and Moen
2004). It is a moderate-sized tree that grows up to $20 \mathrm{~m}$ in height. The bark is shining, reddish white or white, with white horizontals smooth lenticels which was observed in present study too.

High elevation ecosystems of Himalayan region are the most vulnerable geographic regions of the world and are important regions for detecting the patterns of climate change on regional scale. There is a phenomenal increase in temperature as a result of global warming during the past few decades. In Nepal, between 1975 and 2005, mean annual temperature increased at a rate 
of $0.04^{\circ} \mathrm{C} /$ year with a higher rate of increase at high altitudes (Baidya et al. 2007) which in turn has an influence in the distribution and regeneration of tree-line species. The regeneration of Betula utilis (tree line birch) is very low compared to Abies spectabilis (Talispatra) dominant tree - line species.

Betula tree line is slowing and being invaded by Abies tree - line. Regeneration of Betula utilis forest and spatial patterns of seedling distribution in the Manaslu area have not been studied in detail. So this study was undertaken with following specific objectives: 1) to document the community structure of Betula utilis forest, and 2) to study the regeneration pattern.

\section{MATERIALS AND METHODS}

\section{Study site}

The study area was Samagaun valley which lies inside Manaslu Conservation Area, Gorkha district, Central Nepal. The study area (28³4'58.6”'N, 84³8'28.2'”E, elevation 3500 $4000 \mathrm{~m}$ ) lies on north facing slope with average inclination of $34^{\circ}$. The mean annual monsoon precipitation is $190 \mathrm{ml}$ and mean annual temperature is 6 to $10^{\circ} \mathrm{C}$. Samagaun is surrounded by high mountain and traversed by Budhi Gandaki river. Snow melt water is the main source of soil moisture for forest growth.

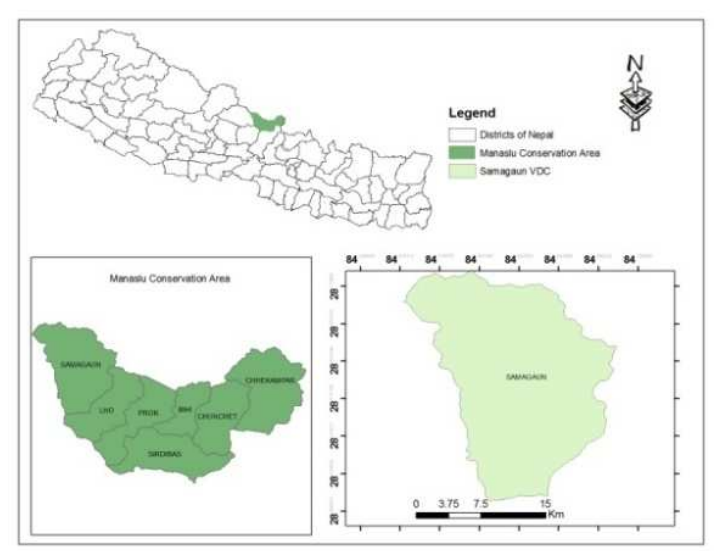

Fig. 1. Map showing study area.

\section{Sampling}

The study site was divided into 5 vertical transects, each representing both mixed and pure forests. In each transect, paired quadrats $(10 \mathrm{~m} \times$ $10 \mathrm{~m}$ ) spaced horizontally about $100 \mathrm{~m}$ apart was sampled at every $100 \mathrm{~m}$ elevation increment from $3500 \mathrm{~m}$ up to $4000 \mathrm{~m}$. Altogether 40 quadrats were sampled. In each square quadrat $(10 \mathrm{~m} \times 10 \mathrm{~m})$, number of individuals of each species in tree stage were counted and diameter at breast height (DBH, measured at $137 \mathrm{~cm}$ above the ground) of each tree measured. Individuals of tree species were divided into three growth stages: trees $(\mathrm{DBH}>10 \mathrm{~cm})$, saplings $(\mathrm{DBH}<10 \mathrm{~cm}$, height $>30 \mathrm{~cm})$ and seedling (height $<30 \mathrm{~cm}$ ) (Sundryal and Sharma 1996). All shrub species present in the quadrat were recorded. Seedlings and saplings present inside the quadrat was counted within $10 \times 10 \mathrm{~m}^{2}$ since they were scattered. In each sampling plot, the number of trees, sapling, and seedlings were counted for each tree species. Diameter at breast height and height of trees were measured. All the tree species were divided into different size classes based on DBH of $5 \mathrm{~cm}$ difference and the size class diagram was developed to analyze regeneration pattern.

\section{Analysis}

The field data were used to calculate frequency, density, basal area and importance value index of tree species following the method described by Zobel et al. (1987) with some modifications. For some of the pairs of variables, scatter diagrams were prepared.

\section{RESULTS AND DISCUSSION}

\section{Community Structure}

The forest is clearly differentiated into two stands. Lower belt $(3500-3800 \mathrm{~m})$ is mixed Betula forest whereas upper belt shows the pure Betula forest. Betula utilis was the dominant tree species with the highest important value index 173.32 in mixed forest and 262.96 in pure forest. Abies spectabilis was the co-dominant tree species with IVI 65.95 in mixed forest and Rhododendron

ECOPRINT VOL 20, 2013 
campanulatum with 38.06 in pure forest. Abies spectabilis and Larix himalaica were present up to $3800 \mathrm{~m}$ only. Rhododendron campanulatum were present above $3700 \mathrm{~m}$. Tree species richness was very low, only four tree species in mixed forest and two in pure forest (Table 1). In pure Betula utilis forest, Rhododendron campanulatum was present only in $20 \%$ of the sampling plots.

Present studied tree species richness (four species) is equitable to the tree species richness (three species) at tree line in Manang area of Trans-Himalayan dry valley in Central Nepal reported by Shrestha et al. (2007). The observation of various forests of the subalpine region of Manang revealed that the tree species such as Betula utilis generally preferred moist northern slope. In present study also, forest of Betula utilis was found only in the north facing slope. Distribution of Betula utilis up to higher altitude is seen in Himalaya as it is adapted well in cold climate. Lower belt of the forest was occupied by Abies spectabilis and Larix himalaica in our study site but in the dry Manang valley, central Nepal, lower belt was dominated by Abies spectabilis and Pinus wallichiana (Ghimire and Lekhak 2007, Shrestha et al. 2007). In a study, Gaire et al. (2010) recorded six tree species from treeline ecotone of Langtang National Park, which is greater than our observation from Himalayan treeline.

Total tree density was more in mixed forest than in pure forest (2054 stems/ha in mixed forest and 1707 stems/ha in pure forest). The total basal area of mixed forest was high $\left(76.55 \mathrm{~m}^{2} / \mathrm{ha}\right)$ than in pure forest $71.00 \mathrm{~m}^{2} / \mathrm{ha}$ ). But the basal area of Betula utilis was found to be less in mixed Betula forest $\left(55.65 \mathrm{~m}^{2} / \mathrm{ha}\right)$ than in pure Betula forest $\left(64.67 \mathrm{~m}^{2} / \mathrm{ha}\right)$ (Table 1$)$. Tree density in present study was higher than the tree density observed by Shrestha et al. (2007) in Manang area and Bhuju et al. (2010) from treeline of Sagarmatha National Park. Bhuju et al. (2010) recorded total basal area of $11.2 \mathrm{~m}^{2} / \mathrm{ha}$ and a density of $445 \mathrm{stems} / \mathrm{ha}$, from treeline and basal area of $18.6 \mathrm{~m}^{2} / \mathrm{ha}$ and a density of 1,034 stems/ha from timberline region. The tree basal areas of Betula utilis increased from $3500 \mathrm{~m}$ to $3800 \mathrm{~m}$ and then get decreased above $3800 \mathrm{~m}$. Similarly the tree basal area of Abies spectabilis and Larix himalaica also get decreased with increase in elevation. Betula utilis in lower altitude $(3500-3600 \mathrm{~m})$ were small with lower basal area than in other elevation (Fig. 2).

Density of Betula utilis increased with increase in elevation where as density of other tree species decreased with increase in elevation (Fig. 3). The most densely populated plots were between 3700 $3800 \mathrm{~m}$ and above $4000 \mathrm{~m}$. The density of Abies spectabilis and Larix himalaica was highest between $3500 \mathrm{~m}$ - $3600 \mathrm{~m}$. Rhododendron campanulatum was found more in between the elevation of $3700 \mathrm{~m}-3800 \mathrm{~m}$. This study observed decrease of total tree density with increase in elevation which is similar to the observation of Shrestha et al. (2007) in the transHimalayan treeline.

Table 1. Structural parameters of tree species.

\begin{tabular}{|c|c|c|c|c|c|c|c|}
\hline \multirow[t]{2}{*}{ SN } & \multirow[t]{2}{*}{ Plant Species } & \multicolumn{3}{|c|}{$\begin{array}{l}\text { Mixed Betula Forest } \\
\quad(3500-3800 \mathrm{~m})\end{array}$} & \multicolumn{3}{|c|}{$\begin{array}{l}\text { Pure Betula Forest } \\
\quad(3800-4000 \mathrm{~m})\end{array}$} \\
\hline & & D (stem/ha) & $\mathrm{BA}\left(\mathrm{m}^{2} / \mathrm{ha}\right)$ & IVI & D (stem/ha) & $\mathrm{BA}\left(\mathrm{m}^{2} / \mathrm{ha}\right)$ & IVI \\
\hline 1. & Betula utilis & 1384 & 55.65 & 173.22 & 1654 & 64.67 & 262.96 \\
\hline 2. & Abies spectabilis & 412 & 11.64 & 65.95 & & & \\
\hline 3. & Larix himalaica & 226 & 7.84 & 51.12 & & & \\
\hline 4. & Rhododendron campanulatum & 32 & 1.42 & 10.12 & 53 & 6.33 & 37.03 \\
\hline & Total & 2054 & 76.55 & & 1707 & 71.00 & \\
\hline
\end{tabular}

Note: $\mathrm{D}=$ Density, BA= Basal Area, IVI= Importance Value Index 


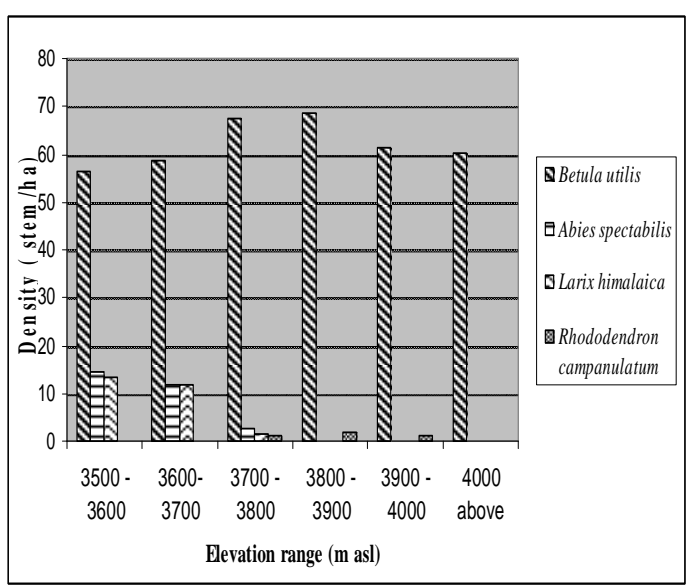

Fig. 2. Basal area of tree species.

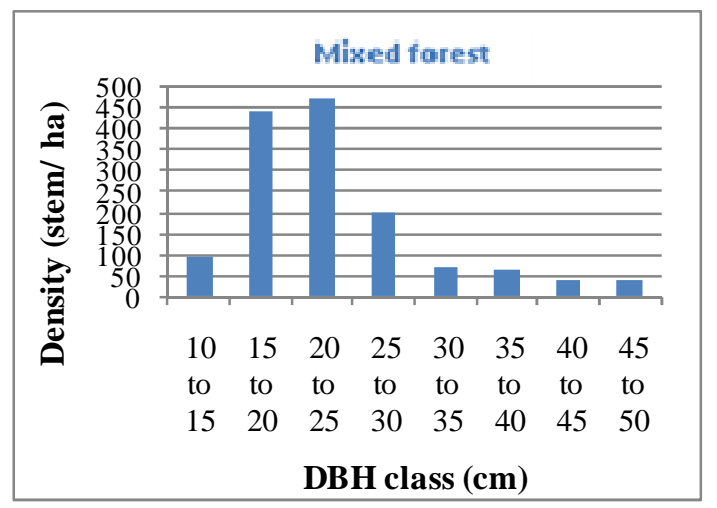

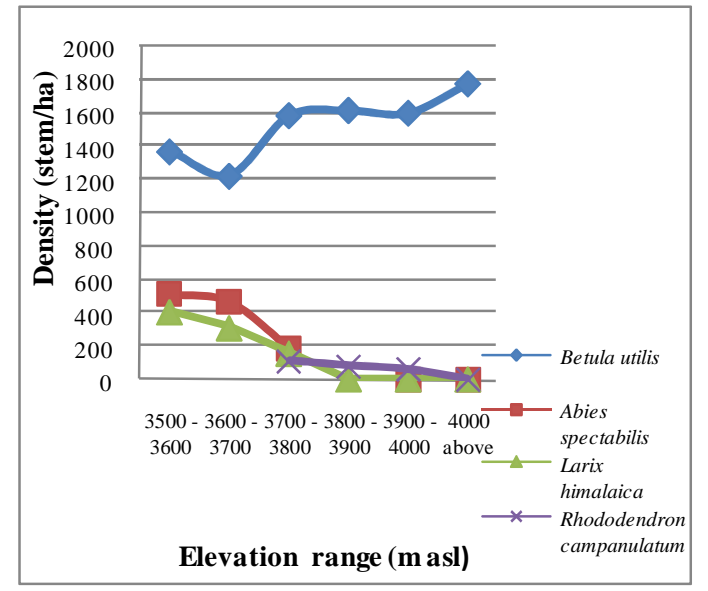

Fig. 3. Density of tree species.

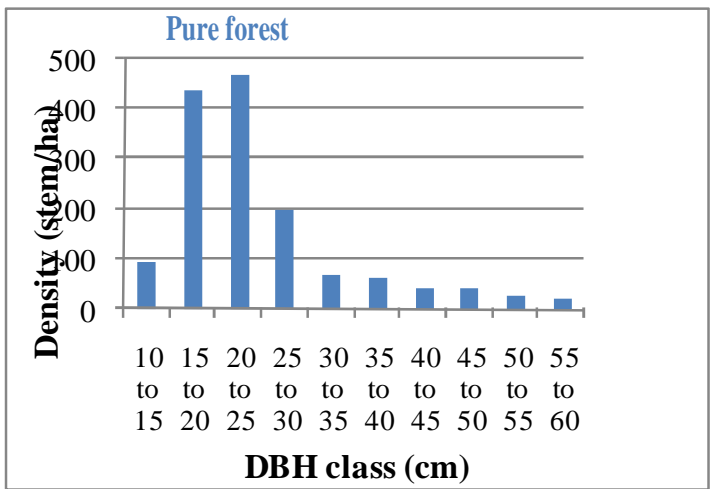

Fig. 4. Density - diameter curve of Betula utilis in MCA.

\section{Regeneration and Size Class Distribution}

The density diameter curve of the tree population of Betula utilis both on mixed and pure forests deviated slightly from the typical reverse $\mathbf{J}$ shaped structure (Fig. 4) which is the indication of regeneration (Vetaas 2002). The size class 15-20 $\mathrm{cm}$ consists of maximum number of individuals and class $10-15 \mathrm{~cm}$ consists of fewer individuals in mixed forest while in pure forest density of trees with DBH $20-25 \mathrm{~cm}$ were highest. Only eight size classes were found in mixed Betula forest while ten size classes were found in pure Betula forest. Trees were smaller in the mixed forest (DBH 10-50 cm) than in pure forest (DBH 10-60 cm). This indicates that the trees in mixed forest are younger than in pure forest as in the Betula forest of dry valley of central Nepal. Absence of higher girth class of
Betula utilis trees (above $50 \mathrm{~cm}$ diameter) in mixed forest might be due to the cutting of larger tress for firewood. The regeneration potential of mixed Betula forest was higher than that of pure Betula forest. An open canopy caused by mild disturbance to the forest allows the growth of seedlings and saplings, which ensures sustainable regeneration (Koirala 2004).

\section{Vegetation in Shrub Layer}

Six species were recorded in shrub layer. Among them Rhododendron anthopogon was the most frequent $(50 \%)$. Others shrubs present in mixed forest of Betula utilis are Rhododendron lepidotum, Berberis aristata, Arudinaria spp. and Sorbus microphylla. 


\section{Seedlings and Saplings Density}

The distribution of saplings and seedlings was not uniform among the sampling plots. There were no saplings in $25 \%$ of the plots and seedlings in $60 \%$. The sapling density in mixed forest was 1136 stems per ha and that in pure forest were 147 stems per ha. The seedling density was 156 stems per ha in mixed forest while that in pure forest was 33 stems per ha.

The sapling density of Abies spectabilis was 648 stems per ha and that of Larix himalaica was 416 stems per ha. The sapling density of both species declined with increase in elevation. The sapling density of Betula utilis was highest at 3500-3600 m and lowest at $4000 \mathrm{~m}$. The sapling density of Betula utilis decreases with increase in elevation (Fig. 5).

The seedling density of Abies spectabilis and Larix himalaica was found to be greater than that of Betula utilis in mixed forest and that of Rhododendron campanulatum was also more than that of Betula utilis in pure forest (Fig. 6).

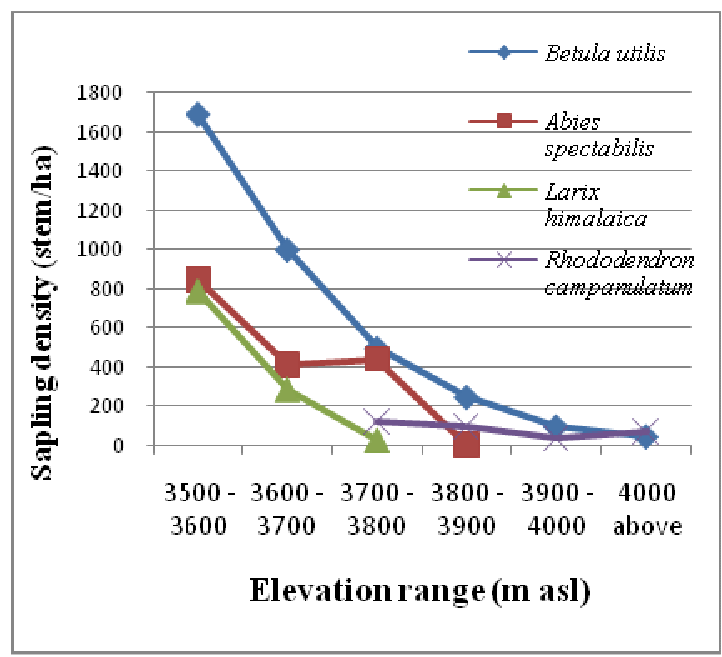

Fig. 5. Density of saplings.

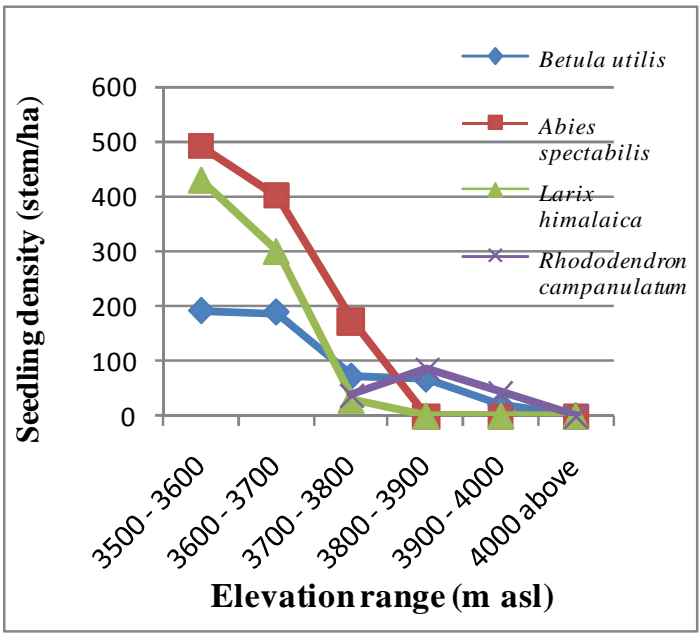

Fig. 6. Density of seedlings.

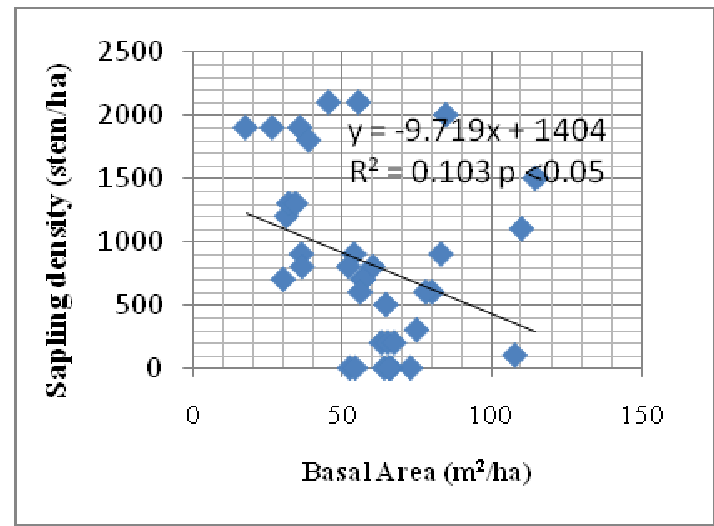

Fig. 7. Scatter diagram showing variation of sapling density with basal area.

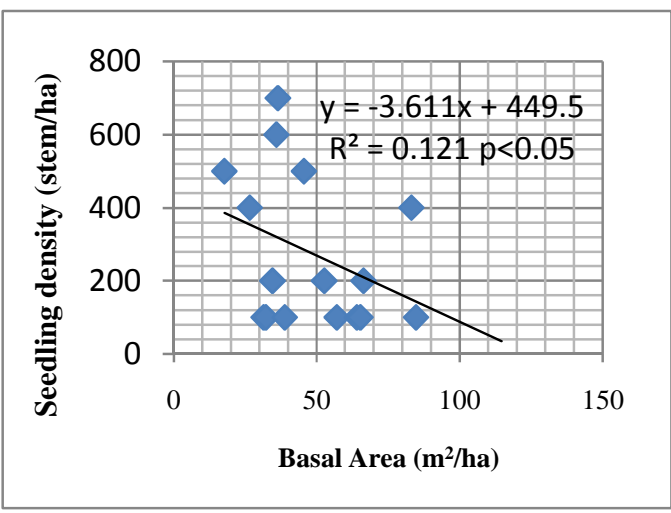

Fig. 8. Scatter diagram showing variationof seedling density with basal area. 
The density of Betula utilis seedlings was highest at the lowest elevation, but it was absent above $4000 \mathrm{~m}$. Both seedling and sapling density decreases with increase in tree density and basal area. Similar type of results was also seen in the Betula forest of Manang done by Shrestha et al. (2007).

Sapling and seedling distribution of Betula utilis was spatially heterogeneous, which may be relatively common under natural conditions. Spatial heterogeneity in sapling and seedling distribution appeared to be determined by light availability caused by variation in canopy cover. The stands with the highest sapling and seedling densities have low basal area (Figs. 7 and 8). According to Carlton and Bazzaz (1998) lack of birch regeneration can be attributable to poor seedling growth and survival rather than inadequate seed dispersal. Low light and thick litter may be the major constraints for seedling establishment of Betula utilis under its own canopy.

Density of seedlings should be greater than the density of saplings for a normal demographic development (West et al. 1981) but in our present study, sapling density was found to be greater than seedling density. Seedlings of the Abies spectabilis and Larix himalaica were more in number than that of Betula utilis in the lower elevation (below $3800 \mathrm{~m}$ ). Seedlings of Abies spectabilis were most abundant and were growing under deep shade. Similarly in high elevation (>3900 m), the seedling and sapling density of Rhododendron campanulatum were higher than that of Betula utilis.

\section{ACKNOWLEDGMENTS}

Field work was financially supported by Nepal Academy of Science and Technology (NAST), Climate and Development Knowledge Network (CDKN) and Nepal Climate Change Knowledge Management Center (NCCKMC). We owe gratitude towards Prof. Dr. Pramod K. Jha for his guidance and support. We are also grateful to the Manaslu Conservation Area Project for giving permission to work and Khwopa College for providing necessary materials for field.

\section{REFERENCES}

Baidya, S.K., R.K. Regmi and M.L. Shrestha. 2007. Climate Profile and Observed Climate Change and Climate Variability in Nepal. Department of Hydrology and Meteorology, Kathmandu.

Bhuju, D.R., M. Carrer, N.P. Gaire, L. Soraruf, R. Riondato, F. Salerno and S.R. Maharjan. 2010. Dendroecological study of high altitude forest at Sagarmatha National Park, Nepal. In: Contemporary Research in Sagarmatha (Mt. Everest) Region, Nepal. (eds.) Jha, P.K. and I.P. Khanal. Nepal Academy of Science and Technology, Lalitpur, pp. 119-130.

Cairns, D. M. and J. Moen. 2004. Herbivory influences treeline. Journal of Ecology 92:99131.

Carlton, G.C. and F.A. Bazzaz. 1998. Regeneration of three sympatric birch species on experimental hurricane blowdown microsites. Ecological Monographs 68:99120.

Gaire, N.P., Y.R. Dhakal, H.D. Lekhak, D.R. Bhuju and H.K. Shah. 2010. Vegetation dynamics in treeline ecotone of Langtang National Park, Central Nepal. Nepal Journal of Science and Technology 11:107-114.

Ghimire, B.K. and H.D. Lekhak. 2007. Regeneration of Abies spectabilis. (D. Don) Mirb. in subalpine forest of Upper Manang, North central Nepal. Local Effects of Global Changes in the Himalayas, Central Department of Botany, Tribhuvan University, Kathmandu, pp. 139-150. 
Koirala, M. 2004. Vegetation composition and diversity of Piluwa micro-watershed in Tinjure-Milke region, east Nepal. Himalayan Journal of Sciences 2(3):29-32.

Sakai, A. and W. Larcher. 1987. Frost survival of plants: Response and adaptation to freezing stress. Ecological Studies 62.

Shrestha, B.B., H.D. Lekhak, B. Ghimire and P.K. Jha. 2007. Regeneration of treeline Birch (Betula utilis D. Don) forest in a TransHimalayan dry valley in central Nepal. Mountain Research and Development 27(3):259-266.

Sundryal, R.C. and E. Sharma. 1996. Anthropogenic pressure on tree structure and biomass in the temperate forest of Mamlay watershed in Sikkim. Forest Ecology and Management 81:113-134.
TISC (Tree Improvement and Silviculture Component). 2002. Forest and vegetation types in Nepal TISC Document. Department of Forest.

Vetaas, O.R. 2002. The effect of environmental factors on the regeneration of Quercus semecarpifolia Sm. in Central Himalaya, Nepal. Plant Ecology 146:137-144.

West, D.C., H.H. Shugart and J.W. Ranney, 1981. Population structure of forests over a large area. Forest Ecology and Management 230:136-150.

Zobel, D.B. and S.P. Singh. 1997. Himalayan forests and ecological generalizations. Bioscience 47: 735-756.

Zobel, D.B., P.K. Jha, M.J. Behan and U.K.R. Yadav. 1987. A Practical Manual for Ecology. Ratna Book Distributors, Kathmandu, Nepal. 